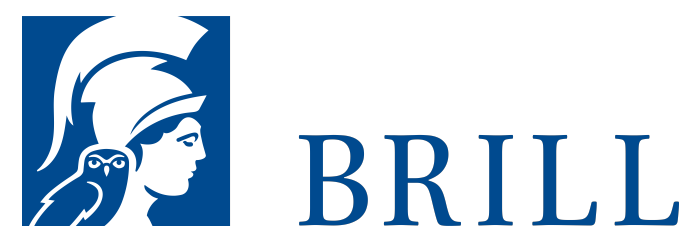

\title{
Studia Papyrologica Varia conscripserunt Instituti alumni
}

Authors: Boswinkel, P.W. Pestman, and Sijpesteijn

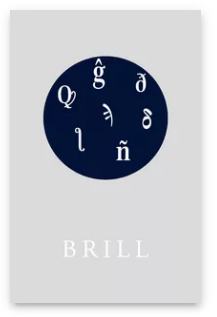

Pages: viii, 120 pp. figures, tables Language: English

Subjects:

General, Classical Studies Publisher: Brill

Series:

Papyrologica Lugduno-

Batava, Volume: 14

E-Book (PDF)

Released online:

23 Mar 2020

ISBN: 978-90-

04-42766-2

List price

USD $\$ 175.00$

Paperback

Publication date: o1 Dec 1965

ISBN: 978-9004-01699-6 
For more information see brill.com

Order information: Order online at brill.com +44330 333 0049 | customerservices@brill.com Submission information: brill.com/authors

Titles published by Brill | Fink, Brill | mentis or Brill | Schöningh: +49(o)715413279216| brill@brocom.de 